\title{
STAVOVI STUDENATA O MUZEJU KAO OKRUŽENJU U KOJEMU SE ODVIJA UČENJE
}

\author{
Dubravka Kuščević ${ }^{1}$, Marija Brajčić ${ }^{2}$, Zvonimira Talijan \\ 1,2 Filozofski fakultet, Sveučilište u Splitu, Hrvatska \\ kuscevic@ffst.hr; mbrajcic@ffst.hr; \\ zvonimiratalijan4@gmail.com
}

Primljeno: 30. 10. 2018.

\begin{abstract}
U suvremenom svijetu muzeji kao kulturne institucije pedagoškom djelatnošću kontinuirano nastoje privući pozornost odgojno-obrazovnih institucija. U teorijskom dijelu rada stavljen je naglasak na muzej i njegovu odgojno-obrazovnu ulogu, pri čemu se opisuju ključni elementi i glavne karakteristike koje obilježavaju učenje u muzeju. U empirijskom dijelu rada predstavljeni su rezultati istraživanja koji donose mišljenja i stavove studenata društvenih i prirodnih znanosti o posjećivanju muzeja, provedbi nastave Likovne kulture u muzejskim prostorima te o muzeju kao prostoru neformalnog učenja.

Ovim istraživanjem obuhvaćeni su studenti na smjerovima Učiteljski studij te Rani i predškolski odgoj i obrazovanje na Filozofskom fakultetu u Splitu, kao i studenti Ekonomskog fakulteta, Prirodoslovno-matematičkog fakulteta te Medicinskog fakulteta u Splitu. U istraživanju je sudjelovalo 158 studenata: 52 studenta prirodnih znanosti $i 106 \mathrm{~s}$ područja društvenih znanosti; 147 ispitanika bile su žene, a 11 muškarci. Rezultati su pokazali da se studenti prirodnih i društvenih znanosti ne razlikuju po svojim stavovima o muzejima odnosno studenti se u velikom broju slažu s tvrdnjama koje izražavaju pozitivne stavove o učenju u muzejskim prostorima.
\end{abstract}

Ključne riječi: kultura, muzej kao okruženje, učenje, studenti, stavovi

\section{Uvod}

Razlika između čovjeka i svih drugih živih bića jest čovjekova sposobnost stvaranja kulture.

»Čovjek i kultura povezani su posebnom sponom: čovjek stvara kulturu, a kultura čovjeku osigurava osobni razvoj.« (Zbryrad, Plenković, 2009, 121) 
Muzej kao kulturna institucija ima ulogu obogatiti ljudsko iskustvo predmetima, običajima i drugim karakteristikama prošlosti i današnjice. Muzejske institucije pomažu stvaranju i razvijanju osobnosti proučavajući i učeći o našim precima, običajima, jednom riječi našoj ali i tuđoj povijesti, o svijetu i svemu onome što nas okružuje.

Glavni zadatak muzeja prije svega je stvoriti muzejsku zbirku, točnije izložbenu djelatnost muzeja. Sljedeći je zadatak svoju zbirku iskoristiti kao izvor informacija o određenim običajima, ljudima, prostorima, predmetima odnosno svemu onome što nam predstavlja prošla ali i sadašnja vremena. Muzeji imaju i tešku ulogu da te sadržaje prikažu na zanimljiv način, da uravnoteže prošlost s ljepotama sadašnjega svijeta u kojemu nam mediji nude svakojake sadržaje koji nas često intelektualno ne obogaćuju, svijeta u kojemu tehnologija preuzima sve više čovjekova vremena te uništava čovjekovu komunikaciju i njegove odnose.

»Uloga i svrsishodnost muzeja i galerija u zadnjim se desetljećima promijenila, naročito u području predstavljanja zbirki. Pokazala se potreba obrazovanja ciljne publike jer su zaposleni u muzejima i galerijama osjetili potrebu za kvalitetnijim odzivom na potrebe suvremenog pluralnog i multikulturnog društva.« (Duh, 2015a, 88)

»Promatrajući i slušajući o muzejskoj zbirci, posjetitelji, a najviše učenici, mogu vizualizirati povijest samog čovjeka i njegov način života« (Ćosić, 2011, 185), a time se ujedno uspostavlja odnos učenika prema određenom muzejskom sadržaju. Tako muzeji postaju mjesta koja se pretvaraju u vremeplove vraćajući posjetitelje u prošlost. Muzej je i prostor koji predstavlja poticajno okruženje u kojemu se afektivno uči.

»Afektivno učenje koje podrazumijeva učenje putem doživljaja izrazito je djelotvorno, jer se emocionalni doživljaji lakše i brže pamte.« (Brajčić, 2014, 45)

Također, Loomis ističe da se

»... afektivni kriteriji baziraju na stečenim osjetilnim reakcijama na izložbene postavke, materijale, vrednote, sklonosti i veoma često se odnose na stjecanje ili promjenu specifičnih stavova.« (Loomis, 1983, 3)

Muzeji su »neformalna okruženja za stjecanje znanja, gdje je učenje motivirano i procesirano kroz promatranje i aktivnost « (Ramey-Gassert, Walberg, 1994, 345).

U tim okruženjima posjetitelji biraju što žele iskusiti, ideje ne moraju biti nužno u sekvencama, prilike za učenje mogu biti fragmentirane 
i nestrukturirane. Ovakav proces učenja može biti drugačiji od učenja koje vežemo za formalna okruženja. Neformalna narav okruženja znači da nije moguće odrediti specifične kontekste i sadržaje kojima su izloženi učenici, dakle oni koji uče. Postoji povećana vjerojatnost da će se u muzejskim ustanovama pojaviti samousmjereno učenje i generaliziranje ponuđenih sadržaja, s obzirom da muzeji teže da se sposobnost učenika poistovjeti sa sadržajem putem osobnog iskustva (Falk, Dierking i Linn, 1986).

Posebna odlika muzeja je eksperimentalna priroda učenja koja se bazira na susretima sa stvarnim objektima. Dakle, to je proces »koji uključuje gledanje, postavljanje pitanja, pregledavanje i uspoređivanje (Sheppard, 1993, 89).

»Učenje u muzejima uključuje oštrenje percepcijskih vještina i razvijanje osjeta znatiželje.« (Voris, Sedzielarz i Blackmon, 1986, 52)

Tako je kod promatranja umjetničkih radova u galeriji vrlo važno na koji način muzejski pedagozi izvode odgojno-obrazovni proces.

»Trebaju biti sposobni uspostaviti komunikaciju između učenika i umjetničkog rada. Doživljen likovni rad može dovesti do likovne reakcije učenika koja predstavlja individualno rješenje svakog učenika i predstavlja novo estetsko iskustvo.« (Duh, 2015b, 190)

Navedeno je posebno značajno u nastavi Likovne kulture, ali i u mnogim drugim nastavnim predmetima.

»U neformalnim okruženjima, kognitivno i afektivno učenje su povezani i mogu nadograditi jedan drugog. Na sličan su način povezani obrazovanje i uživanje.« (Bitgood, Serrell i Thompson, 1994, 61)

Prošlost, sadašnjost i budućnost pripadaju svakom čovjeku. U svakodnevnom životu naša je pozornost više usmjerena k sadašnjim i budućim sadržajima. Ovi su sadržaji, međutim, sazdani na prošlim događajima i iskustvima. Susret prošlosti i sadašnjosti odvija se i u muzejskim prostorima. Prošle i sadašnje generacije upoznaju se i dotiču preko artefakata izloženih u muzejima. Muzejski prostori podsjećaju nas da nismo od danas te da naša baština vuče korijene iz daleke prošlosti. Iako se temeljna muzejska funkcija očituje u prikupljanju, bilježenju i čuvanju prošlosti, ona je polivalentna. Muzeji su također životni i edukacijski prostori namijenjeni korisnicima različite dobi. 
»Muzej kao dio socijalne sredine može biti značajan čimbenik razvoja i zanimljiv prostor izvan obiteljskog odgoja djeteta.« (Brajčić, 2014, 17)

Današnje generacije potrebno je naučiti usmjereno i pažljivo promatrati te opažati kako bi u moru vizualno-virtualnih podražaja odmorili oči na vrijednim i značajnim primjerima umjetničkih djela koja nas okružuju. Upravo takvi primjeri proizlaze iz naše bogate kulturne baštine koja se pohranjuje i njeguje u muzejskim prostorima.

Muzejski ambijent je prostor koji svojom zornošću utječe na učeničku motivaciju i rezultat učenja, stoga je iznimno važno odabrati ga kao prostor u kojemu se učenje događa.

»Odgovarajući likovno pedagoški pristup važan je u svim vrstama likovnih umjetnosti.« (Herzog, Strnad, 2014, 77)

Kako bismo osigurali učenicima osobni rast i razvoj te utjecali na razvoj njihova kulturnoga identiteta, potrebno je njegovati kulturnu baštinu vlastitoga naroda i prenositi je kao dragocjeno blago budućim naraštajima. Upravo očuvanje, njegovanje i promicanje vrijednosti prirodne i kulturne baštine jedan je od ciljeva kvalitetnog odgoja i obrazovanja.

Prilikom učenja u muzeju teorijski sadržaji koji se usvajaju u učionici upotpunjeni su izvornim eksponatima što učeniku omogućuje da osvijesti svoje mogućnosti i zavoli umjetnost i baštinu. Iznošenje teorijskih sadržaja vezanih uz različite nastavne predmete prečesto djeluje apstraktno i daleko za dječje poimanje. Stoga je potrebno upravo neposrednim muzejskim sadržajima i susretima u muzejskim prostorima obogatiti učenička znanja. Aktivnosti koje se događaju na muzejskim radionicama koje nude muzejski kustosi i muzejski pedagozi te ostali djelatnici muzeja pružaju mogućnost stjecanja znanja u korelaciji različitih nastavnih predmeta.

Muzej je prvenstveno institucija zasnovana sa svrhom prikazivanja kulturne baštine javnosti čime ispunjava društvenu ulogu i ima široku publiku koja se sastoji od turista, školske publike (od dječjeg uzrasta do adolescenata) te obrazovanih ljubitelja umjetnosti. Cilj muzeja kao institucije je neprestano povećavati broj što raznovrsnije publike. Učenicima ne može biti prilagođen cijeli sadržaj određenog muzeja ili galerije pa se otvaraju odjeli za djecu, organiziraju prostorije za dječje aktivnosti unutar muzeja te se razvija istraživački rad za različite uzraste. Iz tog razloga razvija se posebna znanstvena disciplina koju nazivamo muzejskom pedagogijom. 
Muzejska pedagogija je područje koje je i danas još uvijek relativno novo te nedovoljno afirmirano. $U$ hrvatskim muzejima uvođenje samog profila muzejskog pedagoga proces je koji još traje. Muzejski djelatnik je profesionalac koji mora imati stručno znanje, znanje metodike, pedagogije, didaktike i komunikacije. Tradicionalno muzej nije bio predviđen za djecu, ponajprije zbog njihove nemirne prirode, potrebe za kretanjem, skakanjem i diranjem predmeta. Danas se to mijenja jer se u muzejima pomoću stručnog osoblja uvode edukativne radionice za djecu i mlade. Učenici s nastavnikom dolaze u muzej u sklopu školskih aktivnosti te se polako uspostavlja istinska suradnja između muzeja i škola. Najčešće aktivnosti u muzejima su kreativne radionice, izložbe dječjih radova, scenske aktivnosti te pokusi. Polako ali sigurno muzej postaje dio dječjega svijeta.

O važnosti muzeja u životu učenika Maroević govori na sljedeći način:

»Posebnost muzeologije je njezina povezanost s predmetima i njihovim kontekstom, unutar ograničenih i zatvorenih muzejskih uvjeta, ali i širih datosti svijeta u kojem žive. To znači gledati na predmete kao na varijablu koja utječe na obogaćivanje ljudske okoline. Jedan od zadataka muzeologije je interpretirati (tumačiti) predmete unutar konteksta. To može biti izazov budućnosti, jer se kontekst predmeta neprestano mijenja i predstavlja istinsku zbiljsku sadašnjost.« (Maroević, 2004, 22)

Najjači utisak na čovjeka uvijek stvaraju elementi iz okoline. Kako bi današnji učenici kad odrastu mogli oblikovati vizualni identitet naše zemlje, potrebno je razvijati ponos zbog bogate kulturne baštine koju posjedujemo i naviku likovno-estetskog vrednovanja okoline. Upravo je kulturna baština most kojim spajamo nastavu, posebno likovnu nastavu, i muzejske prostore. Ona je znatno šira od granica jedne nacije i obogaćuje naše identitete. Kultura prelazi nacionalne granice, a nacionalne kulture čine spektar kulture čovječanstva. Kako bismo razvili kulturni identitet, potrebno je sistematično organizirati i planirati posjete učenika muzejima.

\section{Istraživanje}

\section{Cilj, zadaci i hipoteze istraživanja}

Cilj ovog istraživanja je utvrđivanje stavova studenata društvenih i prirodnih znanosti o posjećivanju muzeja, provedbi nastave Likovne kulture u muzejskim prostorima te o muzeju kao prostoru neformalnog 
učenja. S obzirom na postavljeni cilj istraživanja, formulirani su sljedeći zadatci istraživanja:

1) Istražiti posjećuju li muzeje češće studenti društvenih ili prirodnih znanosti.

2) Istražiti posjećuju li muzeje češće studenti koji su pohađali osnovnu školu u selu ili u gradu.

3) Istražiti stavove studenata o tvrdnji: »Muzejske aktivnosti pogodne su samo za nastavu Likovne kulture.«

4) Istražiti stavove studenata o tvrdnji: »Učenje u muzeju različito je od učenja u učionici.«

5) Utvrditi na kojoj godini studenti Učiteljskog studija najviše posjećuju muzeje.

6) Istražiti stavove studenata o tvrdnji: »Muzejske radionice potaknut će naklonost učenika prema Likovnoj kulturi.»

U istraživanju je postavljena i generalna hipoteza: očekuje se da stavovi studenata društvenih znanosti o učenju u muzeju budu više pozitivni od stavova studenata prirodnih znanosti. S obzirom na postavljeni cilj istraživanja, definirane su sljedeće hipoteze istraživanja:

H1. Studenti društvenih znanosti češće odlaze u muzeje nego studenti prirodnih znanosti.

H2. Studenti koji su osnovnu školu pohađali u gradovima češće posjećuju muzeje od studenata koji su osnovnu školu pohađali na selu.

H3. Studenti prirodnih znanosti skloniji su tvrdnji da su »muzejske aktivnosti pogodne samo za nastavu Likovne kulture» nego studenti društvenih znanosti.

H4. Studenti društvenih znanosti skloniji su tvrdnji »učenje u muzeju različito je od učenja u učionici« nego studenti prirodnih znanosti.

H5. Studenti pete godine Učiteljskog studija više odlaze u muzeje od ostalih studenata.

H6. Studenti društvenih znanosti skloniji su tvrdnji da će »muzejske radionice potaknuti naklonost učenika prema Likovnoj kulturi« nego studenti prirodnih znanosti. 


\section{Uzorak ispitanika, instrument istraživanja i postupak obrade podataka}

Istraživački uzorak na kojem je provedeno istraživanje sastojao se od studenata Filozofskog fakulteta u Splitu s odsjeka Učiteljski studij te Rani i predškolski odgoj i obrazovanje, studenata Ekonomskog fakulteta u Splitu, Prirodoslovno-matematičkog fakulteta u Splitu te studenata Medicinskog fakulteta u Splitu. U istraživanju je sudjelovalo 158 studenata, od toga 52 studenta prirodnih znanosti i 106 s područja društvenih znanosti. Uzorak se sastojao od 147 ispitanica (93 \%) i 11 ispitanika (7\%). Mjerni instrument bio je anonimni anketni upitnik (Prilog 1) koji se sastojao od dva dijela. Prvi dio upitnika odnosio se na opće podatke o ispitanicima kao što su studij, spol, studijska godina te mjesto pohađanja osnovne škole. Drugi dio upitnika sastojao se od 9 tvrdnji vezanih za stavove studenata o nastavi u muzejskim prostorima, s mogućnošću izbora jednog od 5 ponuđenih odgovora koji se odnose na slaganje i/ili neslaganje s ponuđenom tvrdnjom (od potpuno se slažem do potpuno se ne slažem). Za izradu upitnika korištena je Likertova skala. Prije provođenja anketiranja ispitanicima je naglašeno da je upitnik anoniman, a priloženi anketni list posebno je konstruiran za ovu prigodu. Statističke metode analize rezultata bile su aritmetička sredina, $t$-test, standardna devijacija i analiza varijance.

\section{Rezultati i diskusija}

Kako bi se utvrdilo postoji li statistički značajna razlika u učestalosti posjećivanja muzeja između studenata prirodnih i društvenih znanosti, proveden je $t$-test za velike nezavisne uzorke. Prikaz deskriptivnih parametara i rezultata $t$-testa za ispitivanje značajnosti razlike $\mathrm{u}$ učestalosti posjećivanja muzeja između studenata prirodnih ( $\mathrm{N}=52)$ i društvenih znanosti $(\mathrm{N}=106)$ prikazan je u Tablici 1 . Kao pokazatelj učestalosti posjećivanja muzeja uzet je rezultat na tvrdnji broj 6 koja glasi: »Prakticiram samostalni odlazak u muzej.« Analiza rezultata pokazala je da je razlika statistički neznačajna, odnosno da se studenti društvenih i prirodnih znanosti ne razlikuju u učestalosti posjećivanja muzeja, što je vidljivo i na grafičkom prikazu rezultata (Grafikon 1). Budući da se prema prvoj hipotezi pretpostavljalo da će studenti društvenih znanosti češće odlaziti u muzeje od studenata prirodnih znanosti, prva hipoteza nije potvrđena. 
Tablica 1. Učestalost posjećivanja muzeja studenata prirodnih i društvenih znanosti

\begin{tabular}{|c|c|c|c|c|c|}
\hline Varijabla & $\mathbf{M}$ & SD & $\mathbf{T}$ & Df & $\mathbf{P}$ \\
\hline Studenti prirodnih znanosti & 2.77 & 1.41 & \multirow{2}{*}{-0.11} & \multirow{2}{*}{156} & \multirow{2}{*}{0.92} \\
\hline Studenti društvenih znanosti & 2.79 & 1.23 & & & \\
\hline
\end{tabular}

* Razina statističke značajnosti je $5 \%(\mathrm{p}<.05)$

Dakle, iz dobivenih rezultata vidljivo je da se u ovom pitanju nisu pokazale očekivane razlike među dvjema skupinama ispitanika, jer je značajnost na razini višoj od 0.05 .

Grafikon 1. Prosječne vrijednosti procjena učestalosti posjećivanja muzeja studenata prirodnih i društvenih znanosti

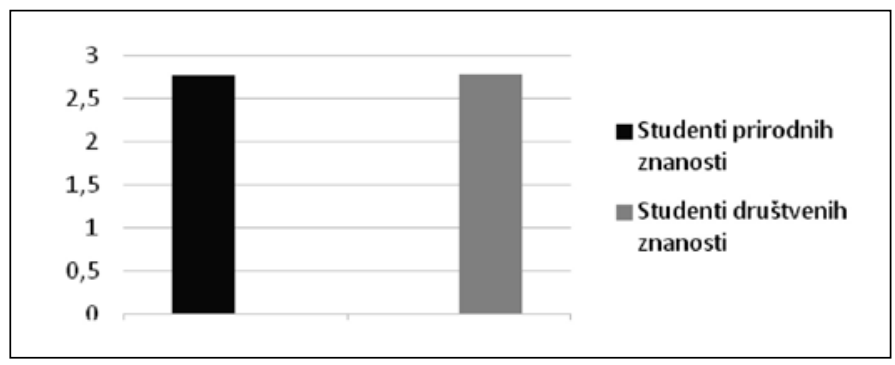

Očekivalo se da će studenti društvenih znanosti, potaknuti različitim kolegijima koje slušaju na svojim fakultetima unutar kojih se ističe važnost suradnje s muzejskim institucijama, imati češću naviku posjećivanja muzejskih prostora. Neka istraživanja provedena šezdesetih godina govore kako su »muzeji sada studijske lokacije za sve vrste društvenih istraživanja« (Rovšnik, 1997, 14). Danas je izazov

»... suvremene muzejske pedagogije povećavanje broja muzejskih posjetitelja i realiziranje kvalitetnih $\mathrm{i}$ atraktivnih edukativnih projekata namijenjenih različitim ciljanim grupama društvene zajednice.«(Cukrov, 1998, 132)

Prednost posjećivanja muzeja je u tome što studenti i prirodnih i društvenih znanosti dolaze $\mathrm{u}$ kontakt $\mathrm{s}$ primarnim izvorima i na temelju svoga vlastitoga iskustva kreiraju nova znanja. Također, studenti, osim što promatraju originalan izvor, istovremeno ga i propituju i time razvijaju vještinu kritičkoga mišljenja. Muzeji omogućuju studentima 
da budu aktivni, uče po načelu zornosti na temelju vlastitoga iskustva $\mathrm{i}$ rada, ali isto tako i u socijalnoj komunikaciji s ostalim sudionicima u muzejskim prostorima. Iako su muzeji pogodni za različite vrste društvenih istraživanja, ohrabrujuće je što studenti i prirodnih i društvenih znanosti podjednako posvećuju pozornost muzejskim sadržajima.

Nakon utvrđivanja navika posjećivanja muzeja od strane studenata Željeli smo istražiti posjećuju li muzeje češće studenti koji su pohađali osnovnu školu u selu ili u gradu. Pri tom smo krenuli od pretpostavke da će studenti koji su osnovnu školu pohađali u gradovima češće posjećivati muzeje od studenata koji su osnovnu školu pohađali na selu.

Prikaz deskriptivnih parametara i rezultata $t$-testa za ispitivanje značajnosti razlike u učestalosti posjećivanja muzeja između studenata koji su pohađali osnovnu školu u selu $(\mathrm{N}=37)$ i studenata koju su je pohađali u gradu ( $\mathrm{N}=121)$ vidljivi su u Tablici 2 i Grafikonu 2.

Tablica 2. Učestalost posjećivanja muzeja studenata koji su pohađali osnovnu školu u selu i u gradu

\begin{tabular}{|c|c|c|c|c|c|}
\hline Varijabla & M & SD & $\mathbf{T}$ & Df & $\mathbf{P}$ \\
\hline $\begin{array}{l}\text { Studenti koji su osnovnu školu } \\
\text { pohađali u selu }\end{array}$ & 2.41 & 1.19 & \multirow{2}{*}{2.10} & \multirow{2}{*}{156} & \multirow{2}{*}{ 0.04 } \\
\hline $\begin{array}{l}\text { Studenti koji su osnovnu školu } \\
\text { pohađali u gradu }\end{array}$ & 2.90 & 1.30 & & & \\
\hline
\end{tabular}

* Razina statističke značajnosti je $5 \%(\mathrm{p}<.05)$

Grafikon 2. Prosječne vrijednosti procjena učestalosti posjećivanja muzeja studenata koji su osnovnu školu pohađali u gradu i studenata koji su osnovnu školu pohađali u selu

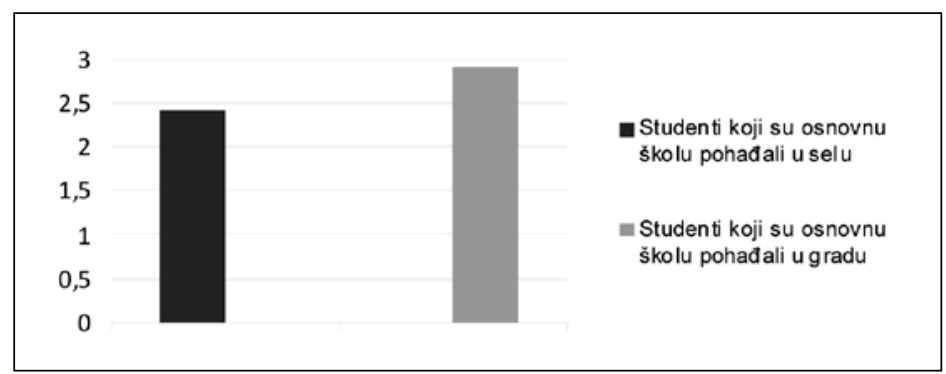

Kako bismo utvrdili postoji li statistički značajna razlika u učestalosti posjećivanja muzeja među studentima koji su osnovnu školu 
pohađali u gradu i studentima koji su osnovnu školu pohađali u selu, proveden je $t$-test za velike nezavisne uzorke. Kao pokazatelj učestalosti posjećivanja muzeja uzet je rezultat na tvrdnji broj 6 koja glasi: »Prakticiram samostalni odlazak u muzej.« Rezultati su pokazali da postoji statistički značajna razlika, odnosno da se dvije navedene skupine razlikuju po učestalosti posjećivanja muzeja. Prosječne vrijednosti procjena učestalosti posjećivanja muzeja pokazuju da studenti koji su osnovnu školu pohađali u gradu češće posjećuju muzeje od onih koji su osnovnu školu pohađali u selu. S obzirom na navedene rezultate, druga hipoteza je potvrđena.

Rezultat je očekivan s obzirom da su studentima iz grada muzeji dostupniji i bliži nego li studentima koji žive na selu. Mnoge gradske škole kod učenika kontinuirano razvijaju naviku posjećivanja muzeja jer se muzejske ustanove najčešće i nalaze u gradskim prostorima. Nekada je seoskim školama bilo teže organizirati posjete muzejima, međutim danas to ne bi trebao biti problem. U odrasloj dobi svi studenti bez obzira na mjesto stanovanja kao budući akademski građani trebali bi imati kulturnu naviku kontakta s muzejima. Ukoliko to nije moguće studentima koji žive na selu, trebalo bi osvijestiti da mnogi muzeji neprestano rade na poboljšavanju i razvijanju vlastite informatičke i informacijske infrastrukture, odnosno imaju svoje mrežne stranice kako bi lakše i jednostavnije korisnicima prenijeli podatke iz svojih baza. Uz pomoć mrežnih stranica muzejima je omogućeno predstavljanje i širenje informacija o njihovom djelovanju izvan prostora muzeja. Tako mnogi domaći i svjetski muzeji na svojim mrežnim stranicama imaju digitalne virtualne zbirke čime se ostvaruje uspješno povezivanje muzeja i njihove publike. Tako se može ostvariti kvalitetna komunikacija u virtualnom prostoru.

»Svijet se budi u virtualnoj stvarnosti, sve prisutnijoj i u muzejskoj struci. Nova vremena nose nove izazove. Ono što je sigurno jest to da je internet promijenio gotovo sve aspekte življenja, a muzeje posebno.« (Šilić, 2016, 270)

U suvremenom svijetu muzeji su postali dostupni bez obzira na mjesto stanovanja. Odnosno, kao što ističe Mosio:

»Muzej, u ovakvom ili nekom drugom obliku, i dalje će biti mjesto koje nas potiče, pa makar i nagnute nad bazu muzejskih podataka na računalu.« (Mosio, 2002, 227)

Kako bismo dobili odgovor na sljedeće istraživačko pitanje, trebali smo utvrditi postoji li statistički značajna razlika u slaganju s tvrdnjom 
da su »muzejske aktivnosti pogodne samo za nastavu Likovne kulture«. Prilikom formiranja ove tvrdnje mislilo se na to da su aktivnosti učenja u muzeju općenito korisne. Između studenata prirodnih i društvenih znanosti proveden je $t$-test za velike nezavisne uzorke. $\mathrm{U}$ analizu ovog rezultata krenuli smo od pretpostavke da će se studenti prirodnih znanosti više složiti s tvrdnjom 9 da su »muzejske aktivnosti pogodne samo za nastavu Likovne kulture « nego studenti društvenih znanosti.

Prikaz deskriptivnih parametara i rezultata $t$-testa za ispitivanje značajnosti razlike u slaganju s tvrdnjom da su muzejske aktivnosti pogodne samo za nastavu Likovne kulture između studenata prirodnih $(\mathrm{N}=52)$ i društvenih znanosti $(\mathrm{N}=106)$ nalazi se u Tablici 3.

Tablica 3. Muzejske aktivnosti pogodne su samo za nastavu Likovne kulture

\begin{tabular}{|l|c|c|c|c|c|}
\hline \multicolumn{1}{|c|}{ Varijabla } & M & SD & T & Df & P \\
\cline { 1 - 3 } Studenti prirodnih znanosti & 2.12 & 1.18 & \multirow{2}{*}{1.57} & \multirow{2}{*}{156} & \multirow{2}{*}{0.12} \\
\cline { 1 - 4 } Studenti društvenih znanosti & $\mathbf{1 . 8 3}$ & $\mathbf{1 . 0 2}$ & & & \\
\hline
\end{tabular}

* Razina statističke značajnosti je $5 \%(\mathrm{p}<.05)$

Rezultati su pokazali da ne postoji statistički značajna razlika, odnosno da se dvije navedene skupine studenata ne razlikuju u svom mišljenju da su muzejske aktivnosti pogodne samo za nastavu Likovne kulture. Prosječne vrijednosti procjene slaganja s prethodno navedenom tvrdnjom (Grafikon 3) pokazuju da su studenti društvenih znanosti uglavnom odgovarali da se ne slažu s navedenom tvrdnjom. S obzirom na ove rezultate, treća hipoteza nije potvrđena.

Grafikon 3. Prosječne vrijednosti procjena slaganja studenata prirodnih i društvenih znanosti s tvrdnjom da su muzejske aktivnosti pogodne samo za nastavu Likovne kulture

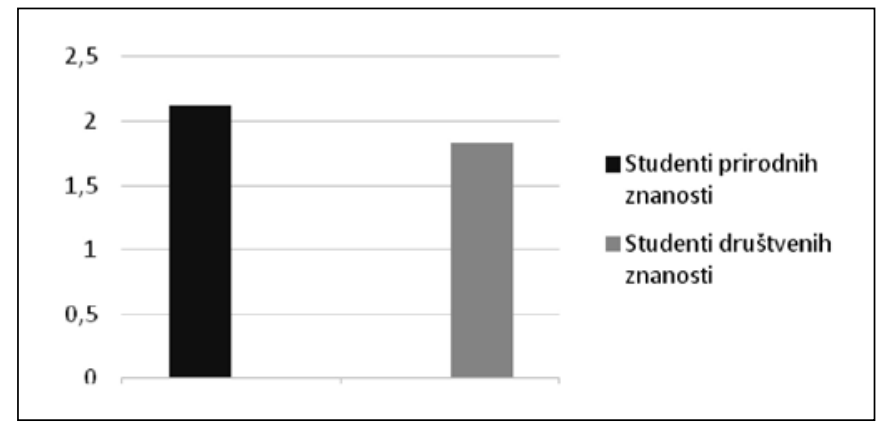


Za pretpostaviti je bilo da će se mišljenja ovih dviju skupina razlikovati zbog predrasuda koje su prisutne o muzejskim radionicama. Uočavamo da se ove dvije skupine ispitanika ne razlikuju u stavovima. Često se smatra da su muzejske radionice isključivo radionice $\mathrm{s}$ fokusom na umjetničkom stvaranju, što naravno nije točno. Likovne radionice u muzejima često prevladavaju u muzejskoj ponudi i namijenjene su učenicima, ali nisu jedini sadržaji koje muzeji nude u svojim aktivnostima. Studenti, što je iznimno dobro, spoznaju da se mnogi sadržaji mogu učiti u suradnji s muzejskim djelatnicima i koristeći muzejski sadržaj. Isto tako mnogi muzeji u svojim prostorima organiziraju predavanja, seminare, simpozije, okrugle stolove, kongrese, tečajeve što muzejskim ustanovama daje dinamičnost te muzeji postaju važnim mjestima za učenje, što studenti i prepoznaju.

Učenje koje se odvija u muzejima, događa se na drugačiji način od učenja u učionicama. Na koji način studenti doživljavaju učenje u učionici i učenje u muzeju željeli smo istražiti u novom istraživačkom zadatku. Pretpostavili smo da će se studenti društvenih znanosti više složiti s tvrdnjom »učenje u muzeju različito je od učenja u učionici« nego studenti prirodnih znanosti jer imaju više znanja o neformalnim oblicima učenja.

Da bismo utvrdili postoji li statistički značajna razlika između studenata prirodnih i društvenih znanosti u slaganju s tvrdnjom »učenje u muzeju različito je od učenja u učionici« proveden je $t$-test za velike nezavisne uzorke. Prikaz deskriptivnih parametara i rezultata $t$-testa za ispitivanje značajnosti razlike u slaganju s navedenom tvrdnjom između studenata prirodnih $(\mathrm{N}=52)$ i društvenih znanosti $(\mathrm{N}=106)$ vidljiv je u Tablici 4.

Tablica 4. Učenje u muzeju različito je od učenja u učionici

\begin{tabular}{|l|c|c|c|c|c|}
\hline \multicolumn{1}{|c|}{ Varijabla } & M & SD & T & Df & P \\
\cline { 1 - 3 } Studenti prirodnih znanosti & 3.62 & 1.30 & \multirow{2}{*}{-1.62} & \multirow{2}{*}{156} & \multirow{2}{*}{0.11} \\
\cline { 1 - 4 } Studenti društvenih znanosti & $\mathbf{3 . 9 2}$ & $\mathbf{0 . 9 7}$ & & & \\
\hline
\end{tabular}

* Razina statističke značajnosti je $5 \%(\mathrm{p}<.05)$

Rezultati su pokazali da ne postoji statistički značajna razlika, odnosno da se dvije navedene skupine ispitanika ne razlikuju u mišljenju da je besmisleno učenje u muzeju mjeriti na isti način kao i u učionici. Prosječne vrijednosti procjena mišljenja o toj tvrdnji (Grafikon 4) po- 
kazuju da su studenti društvenih i prirodnih znanosti uglavnom odgovarali da nemaju stav o toj tvrdnji ili da se uglavnom slažu s navedenom tvrdnjom.

Grafikon 4. Prosječne vrijednosti procjena slaganja studenata prirodnih i društvenih znanosti s tvrdnjom »učenje u muzeju različito je od učenja u učionici«

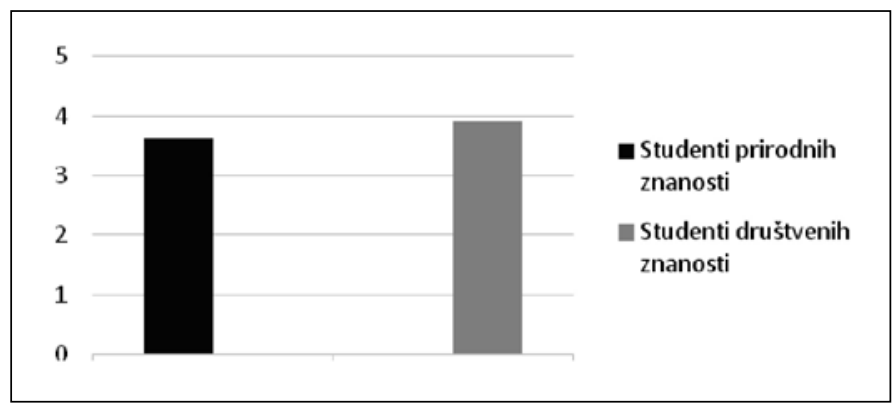

Rezultati pokazuju nešto slabiju osviještenost studenata društvenih znanosti kada je riječ o neformalnom učenju, u ovom slučaju o obliku učenja u muzeju. Neformalno učenje je učenje koje se odvija u okruženjima i situacijama koje su privremene. Ovakvo učenje nije strogo strukturirano i zabavnije je, a ishodi učenja ne vrednuju se na konvencionalne načine.

Brajčić, Kovačević i Kuščević (2013) posebno vrednuju muzeje kao mjesta u kojima se odvija neformalno obrazovanje te navode:

»Muzeji su neformalna okruženja za učenje, u kojima je učenje istinski motivirano i procesirano preko znatiželje, promatranja i raznih aktivnosti. Proces takva učenja može biti drugačiji od procesa učenja koje vežemo uz formalna okruženja. Posebna prilika koju muzeji nude jest eksperimentalna priroda učenja koja se temelji na susretima sa stvarnim objektima. U neformalnim okruženjima kognitivno i afektivno učenje su povezani i mogu se nadograditi.« (Brajčić, Kovačević i Kuščević, 2013, 159)

Spomenuti autori ističu kako vrlo osobna priroda učenja u muzejima, kratko vrijeme u kojemu su učenici uključeni u ovo specifično iskustvo, ali i individualni kontekst u kojemu se ono pojavljuje čini besmislenim pokušaj da se učenje u muzeju mjeri na isti način kao i učenje u učionici (Brajčić, Kovačević i Kuščević, 2013).

S obzirom da studenti Učiteljskog studija u okvirima različitih nastavnih predmeta posjećuju muzeje, željeli smo istražiti učestalost posje- 
ćivanja muzeja. Krenuli smo od pretpostavke da će studenti pete godine učiteljskog studija više odlaziti u muzeje od ostalih studenata. Pri odabiru godina studija koje smo uključili u istraživanje izostavili smo prvu godinu, jer smo smatrali da zbog nastavnoga programa nisu bili uključeni u posjećivanje muzeja. Iz tog smo razloga odlučili anketirati drugu godinu studija, a potom posljednje dvije godine studija kako bismo vidjeli postoji li uzlazni trend posjećivanja muzeja u kasnijim godinama studiranja, a koji se bazira na razvoju navike.

Kako bismo utvrdili postoji li statistički značajna razlika u učestalosti posjećivanja muzeja između studenata druge, četvrte i pete godine Učiteljskog studija, provedena je jednosmjerna analiza varijance za nezavisne uzorke. Deskriptivni parametri procjena učestalosti posjećivanja muzeja studenata druge $(\mathrm{N}=7)$, četvrte $(\mathrm{N}=4)$ i pete godine Učiteljskog studija $(\mathrm{N}=29)$ prikazani su u Tablici 5. U Tablici 6 prikazani su rezultati testiranja značajnosti razlika jednosmjernom analizom varijance u učestalosti posjećivanja muzeja između studenata druge $(\mathrm{N}=7)$, četvrte $(\mathrm{N}=4)$ i pete godine $(\mathrm{N}=29)$ Učiteljskog studija.

Tablica 5. Učestalost posjećivanja muzeja studenata druge, četvrte i pete godine Učiteljskog studija

\begin{tabular}{|l|c|c|}
\hline \multicolumn{1}{|c|}{ Varijabla } & $\boldsymbol{M}$ & $\boldsymbol{S D}$ \\
\hline Studenti 2. godine Učiteljskog studija & 2.57 & $\mathbf{1 . 5 1}$ \\
\hline Studenti 4. godine Učiteljskog studija & 2.50 & $\mathbf{0 . 5 7}$ \\
\hline Studenti 5. godine Učiteljskog studija & 3.28 & $\mathbf{1 . 1 6}$ \\
\hline
\end{tabular}

Tablica 6. Učestalost posjećivanja muzeja studenata druge, četvrte i pete godine Učiteljskog studija (analiza varijance)

\begin{tabular}{|l|r|r|r|r|c|}
\hline \multicolumn{1}{|c|}{ Izvor varijabiliteta } & \multicolumn{1}{c|}{ SS } & \multicolumn{1}{c|}{ df } & \multicolumn{1}{c|}{ MS } & F & P \\
\hline BS & 163.05 & 1 & 163.05 & & \\
\hline Godina Učiteljskog studija & 4.27 & 2 & 2.13 & 1.50 & 0.24 \\
\hline Pogreška & 52.51 & 37 & & & \\
\hline
\end{tabular}

* Razina statističke značajnosti je 5\% $(\mathrm{p}<.05)$

Rezultati su pokazali da ne postoji statistički značajan utjecaj godine studija na Učiteljskom studiju na učestalost posjećivanja muzeja studenata. Drugim riječima, studenti s promatranih godina studija na Učiteljskom studiju jednako često posjećuju muzeje. Iz grafičkog pri- 
kaza prosječnih vrijednosti procjena učestalosti posjećivanja muzeja (Grafikon 5) vidljivo je da njihovi odlasci i nisu tako česti. S obzirom na navedene rezultate, peta hipoteza nije potvrđena.

Grafikon 5. Prosječne vrijednosti procjena učestalosti posjećivanja muzeja studenata druge, četvrte i pete godine Učiteljskog studija

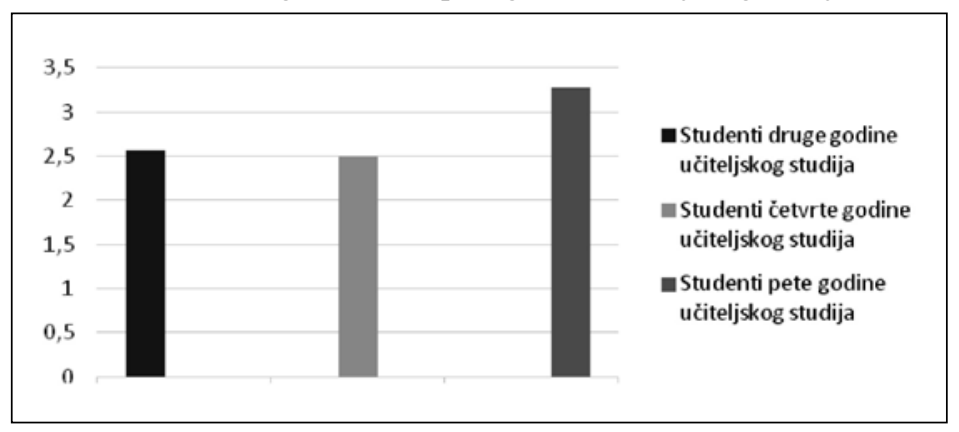

Tijekom studiranja potrebno je studentima osvijestiti važnost muzeja jer sadržaji u muzeju potiču razvoj učenika u svim razvojnim područjima (intelektualnom, socijalnom, tjelesnom i emocionalnom), a sadržaji su osmišljeni i prezentirani na način da učenicima omogućavaju prilagođavanje individualnim potrebama i različitostima. Ako student - budući učitelj - nema naviku posjećivanja muzeja, teško će tu naviku razviti kod svojih učenika. Iz toga razloga je važno da budući učitelji surađuju s muzejskim pedagozima kako bi programi učenja u muzeju bili primjereni i kvalitetni.

$\mathrm{Na}$ kraju istraživanja utvrdili smo stavove studenata prema muzejskim radionicama i Likovnoj kulturi. Pretpostavili smo da će se studenti društvenih znanosti više složiti s tvrdnjom da će »muzejske radionice potaknuti naklonost učenika prema Likovnoj kulturi« nego studenti prirodnih znanosti. S ciljem utvrđivanja postojanosti statistički značajne razlike između studenata prirodnih i društvenih znanosti u slaganju s ovom tvrdnjom, proveden je $t$-test za velike nezavisne uzorke. Iako su ispitanici studenti različitih fakulteta, smatrali smo da im njihovo prethodno obrazovanje daje kredibilitet za validne procjene ove tvrdnje. Prikaz deskriptivnih parametara i rezultata $t$-testa za ispitivanje značajnosti razlike između studenata prirodnih $(\mathrm{N}=52)$ i društvenih znanosti $(\mathrm{N}=106)$ u slaganju s tvrdnjom da će muzejske radionice potaknuti naklonost učenika prema Likovnoj kulturi vidljiv je u Tablici 7. 
Tablica 7. Muzejske radionice potaknuti će naklonost učenika prema Likovnoj kulturi

\begin{tabular}{|l|c|c|c|c|c|}
\hline \multicolumn{1}{|c|}{ Varijabla } & M & SD & T & Df & p \\
\cline { 1 - 3 } Studenti prirodnih znanosti & 3.71 & 0.99 & \multirow{2}{*}{-2.16} & \multirow{2}{*}{156} & \multirow{2}{*}{$\mathbf{0 . 0 3}^{*}$} \\
\cline { 1 - 3 } Studenti društvenih znanosti & $\mathbf{4 . 0 6}$ & $\mathbf{0 . 9 1}$ & & & \\
\hline
\end{tabular}

* Razina statističke značajnosti je $5 \%(\mathrm{p}<.05)$

Rezultati su pokazali da postoji statistički značajna razlika, odnosno da se dvije navedene ispitane skupine razlikuju u mišljenju. Prosječne vrijednosti procjena slaganja s tom tvrdnjom (Grafikon 6) pokazuju da se studenti društvenih znanosti više slažu s tom tvrdnjom nego studenti prirodnih znanosti, odnosno da smatraju da će muzejske radionice potaknuti naklonost učenika prema umjetnosti. S obzirom na navedene rezultate, šesta hipoteza je potvrđena.

Grafikon 6. Prosječne vrijednosti procjena slaganja studenata prirodnih i društvenih znanosti s tvrdnjom da će muzejske radionice potaknuti naklonost učenika prema Likovnoj kulturi

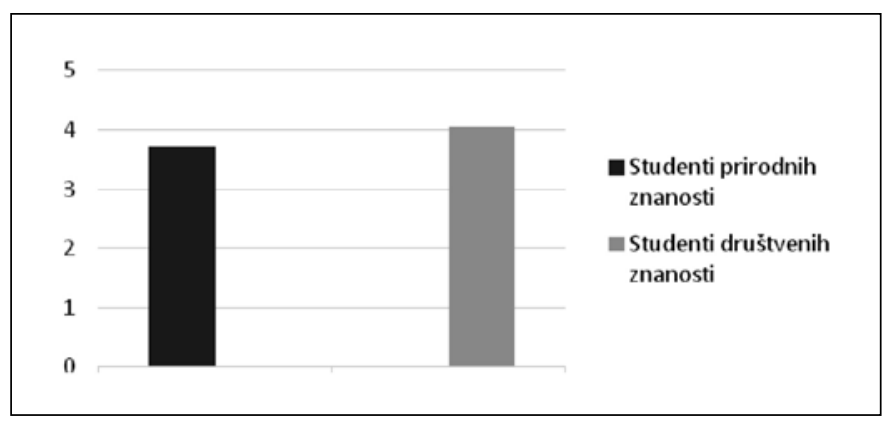

Studenti društvenih znanosti (posebno studenti Učiteljskog studija) upoznati su s djelovanjem muzejskih pedagoga, a također su upoznati i s učeničkim likovnim radovima koji su nastali na likovnim radionicama u muzejima, stoga ne čudi njihov pozitivan stav o ovoj temi.

Kako bismo ispitali postavljenu glavnu hipotezu, bilo je potrebno utvrditi jesu li stavovi o učenju u muzeju studenata društvenih znanosti pozitivniji od stavova studenata prirodnih znanosti. Kao mjeru stava uzeli smo ukupan rezultat izračunat kao zbroj procjena (odgovora) na ove tvrdnje koje se odnose na likovne aktivnosti u muzeju: 
- učenje je intenzivnije pomoću vizualnog doživljaja;

- doživljaj često nadilazi riječi;

- učenje u muzeju povezuje kognitivno i afektivno učenje;

- učenje u muzeju učinkovito je za djecu;

- likovne muzejske radionice potiču kreativnost $\mathrm{i}$ inovativnost.

Kako bismo utvrdili postoji li statistički značajna razlika u stavovima o učenju u muzeju između studenata prirodnih i društvenih znanosti, proveden je $t$-test za velike nezavisne uzorke. Rezultati su pokazali da ne postoji statistički značajna razlika, odnosno da se dvije navedene skupine ne razlikuju u stavovima o učenju u muzeju (Tablica 8 i Grafikon 7).

Tablica 8. Usporedba stavova o učenju u muzeju između studenata prirodnih i društvenih znanosti

\begin{tabular}{|l|c|c|c|c|c|}
\hline \multicolumn{1}{|c|}{ Varijabla } & M & SD & T & Df & P \\
\cline { 1 - 3 } Studenti prirodnih znanosti & 21.81 & 2.89 & \multirow{2}{*}{-1.93} & \multirow{2}{*}{156} & $\mathbf{0 . 0 5}$ \\
\cline { 1 - 4 } Studenti društvenih znanosti & $\mathbf{2 2 . 5 6}$ & $\mathbf{1 . 9 3}$ & & & \\
\hline
\end{tabular}

* Razina statističke značajnosti je $5 \%(\mathrm{p}<.05)$

Grafikon 7. Prosječne vrijednosti procjena stavova o učenju u muzeju studenata prirodnih i društvenih znanosti

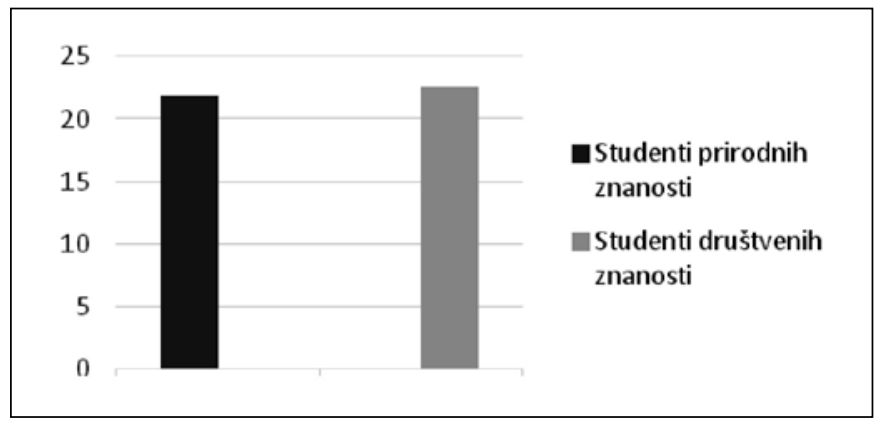

Analizom tvrdnji koje su uključene u analizu kao mjera stavova o učenju u muzeju vidljivo je da su studenti društvenih i prirodnih znanosti imali iste stavove o tomu da je učenje intenzivnije pomoću vizualnog doživljaja, da doživljaj često nadilazi riječi, zatim da učenje u 
muzeju povezuje kognitivno i afektivno učenje, da je učinkovito za djecu te da muzejske radionice potiču dječju kreativnost i inovativnost. S obzirom na navedene rezultate, glavna hipoteza nije potvrđena, iako je razina statističke značajnosti na samoj granici, što nam daje poticaj za nastavak istraživanja na temu stavova studenata o neformalnom obliku učenja, u ovom slučaju učenja u muzeju.

\section{Zaključna razmatranja}

Učenje u muzeju otvara vrata i učenicima i učiteljima za suvremene načine rada, korištenje novih metoda te povezivanje različitih područja i djelatnosti. Takvo učenje u okvirima nastave omogućava komunikacija koja se događa između učenika, muzejskog eksponata i muzejskog pedagoga. Ovaj proces nije nužno usmjeren samo na jedno područje, jer je moguće učenje u muzeju učiniti izvorom širokog znanja i ostvarenja zadanih ciljeva iz više nastavnih predmeta. Upravo prostor muzeja približava djetetu prirodu, kulturu i baštinu koja će ga, kroz učinkovitu suradnju roditelja, odgojitelja i ostalih sudionika ovoga procesa dovesti do otkrivanja novih znanja i spoznaja.

Rezultati istraživanja i njihova analiza pokazuju:

- da se studenti društvenih i prirodnih znanosti ne razlikuju u procjeni važnosti muzeja u nastavi;

- da se studenti uglavnom slažu s pozitivnim stavovima o neformalnom učenju u muzeju;

- da studenti društvenih znanosti imaju pozitivne stavove o razvoju naklonosti prema nastavi Likovne kulture nakon učenja u muzeju;

- da su studenti koji su osnovnu školu pohađali u gradu stekli naviku češćeg posjećivanja muzejskih prostora od studenata koji su osnovnu školu pohađali na selu.

Od šest hipoteza koje su postavljene u ovom istraživanju, potvrđene su dvije. Prva hipoteza koja glasi da studenti društvenih znanosti češće posjećuju muzeje nije potvrđena, što je ohrabrujuće, jer se pokazalo da i studenti prirodnih znanosti jednako pokazuju interes za muzejske sadržaje. Druga hipoteza o tome da studenti koji su osnovnu školu završili u gradu češće posjećuju muzej je potvrđena, što govori u prilog teoretskim razmatranjima u kojima se ukazuje na važnost ranog 
stvaranja navike posjećivanja muzeja. Treća hipoteza - da su studenti prirodnih znanosti skloniji tvrdnji da su muzejske aktivnosti pogodne samo za nastavu Likovne kulture od studenata društvenih znanosti - nije potvrđena. Ovaj rezultat također ohrabruje jer studenti shvaćaju da muzeji kao neformalni prostori za učenje nisu namijenjeni samo umjetničkom razvoju nego postoji i niz prirodoslovnih i tehničkih muzeja u kojima se također učinkovito može izvoditi nastava iz prirodnih predmeta. Četvrta hipoteza nije potvrđena jer studenti i društvenih i prirodnih znanosti imaju isti stav prema tvrdnji da je učenje u muzeju različito od učenja u učionici. Učenje u muzeju ima komponentu emocionalnog doživljaja koja utječe na bolje pamćenje te afektivno učenje koje se odvija u muzeju ima bolji učinak. Međutim, očito da studenti nemaju ta saznanja te se nisu mogli izjasniti u tom smislu. Peta hipoteza odnosila se samo na studente Učiteljskog studija te je pretpostavila da u muzeje najviše odlaze studenti pete godine tog studija. Ova hipoteza također nije potvrđena, jer se pokazalo da studenti svih godina Učiteljskog studija jednako posjećuju muzeje te da ne postoji statistički značajna razlika. Ovaj rezultat pokazuje i da na Učiteljskom studiju gdje se školuju studenti koji će odgajati buduće naraštaje postoji visoko razvijena svijest o važnosti uključivanja muzejskih sadržaja u odgojnoobrazovni proces. Suprotno očekivanjima da će rezultat ići u korist studenata pete godine studija, istraživanje je pokazalo da i studenti ostalih godina studija također posjećuju muzeje. U ovom slučaju pohvala ide i profesorima koji potiču studente unutar svojih kolegija na odlazak u muzeje, a moguće i sami preusmjeravaju nastavu prema muzejima. Potvrđena je šesta hipoteza koja je pretpostavila da su studenti društvenih znanosti skloniji tvrdnji da će »muzejske radionice potaknuti naklonost učenika prema Likovnoj kulturi« nego studenti prirodnih znanosti. Ovaj rezultat bio je očekivan jer se studente društvenih znanosti na različitim kolegijima tijekom njihova studija više potiče da razmišljaju u tom smjeru. Rezultati ukazuju na pozitivne stavove studenata budućih sudionika u odgojno-obrazovnom procesu i onih koji to neće biti s obzirom na buduće zanimanje prema muzejima i njihovom značaju u procesu stjecanja znanja. 


\section{Literatura}

Bitgood, Stephen; Serrell, Beverly i Thompson, Don (1994), »The impact of informal education on visitors to museums «, u: Crane, V.; Nicholson, H.; Chen, M. i Bitgood, S. (ur.), Informal Science Learning, Washington, Research Communication Ltd, str. 61-106.

Brajčić, Marija; Kovačević, Sonja i Kuščević, Dubravka (2013), »Učenje u muzeju«, Hrvatski časopis za odgoj i obrazovanje, 15(Sp.Ed.2), str. 159-178.

Brajčić, Marija (2014), Arheološki parkovi u Hrvatskoj, stanje i perspektive, Split: Filozofski fakultet.

Cukrov, Tončika (1998), »Učenje u muzejima«, Informatica museologica, 29(12), str. 132.

Ćosić, Slavica (2011), »Sat povijesti u muzeju krapinskih neandertalaca«, Život $i$ škola: časopis za teoriju i praksu odgoja i obrazovanja, LVII(25), str. 185192.

Duh, Matjaž (2015a), »The function of museum pedagogy in the development of artistic appreciation«, Revija za elementarno izobraževanje, 8(4), str. 87-101.

Duh, Matjaž (2015b), »Die Rolle von Galerien und Museen bei der Entwicklung der künstlerischen Fähigkeiten/Fertigkeiten von Schüler/inne/n der Gesamtschule (6-bis 15-jährige Pflichtschüler/innen)«, u: Fleischmann, Otakar (ur.), The Teaching Profession: New Challenges - New Identities?, Austria: Forschung und Wissenschaft, Erziehungswissenschaft, Bd. 22, Münster: LIT, str. 185-194.

Falk, John H.; Koran, John J. i Dierking, Linn D. (1986), »The things of science: Assessing the learning potential of science museums«, Science Education, 70(5), str. 503-508.

Loomis, Ross J. (1983), Four Evaluation Suggestions to Improve Effectiveness of Museum Labels, Texas: Historical Commission.

Herzog, Jerneja i Strnad, Brigita (2014), »Proaktivnost slepih in slabovidnih pri dojemanju abstraktne in figuralne umetnosti«, Revija za elementarno izobraževanje, 7(3/4), str. 75-88.

Maroević, Ivo (2004), Baštinom u svijest, Petrinja: Ogranak Matice hrvatske.

Mosio, Grażyna (2002), »Trebamo li se bojati propasti muzeologije? Muzeji i nove komunikacijske tehnologije«, Etnološka istraživanja, 8, str. 209-228.

Ramey-Gassert, Linda i Walberg, Herbert J. (1994), »Reexamining connections: Museums as science learning environments«, Science Education, 78(4), str. 345-363.

Rovšnik, Borut (1997), »Istraživanje muzejske publike«, Informatica museologica, 28(1-4), str. 14-17. 
Sheppard, Beverly (1993), »Aspects of a successful field trip«, u: Sheppard, Beverly (ur.), Building Museum and School Partnerships, Washington: American Association of Museum, str. 38-52.

Šilić, Ervin (2016), »Nastajanje mrežnih stranica MDC-a«, Muzeologija, 53, str. 263-271.

Voris, Helen; Sedzielarz, Maija i Blackmon, Carolin (1986), Teach the Mind, Touch the Spirit, Chicago: Field Museum of Natural History.

Zbryrad, Teresa i Plenković, Juraj (2009), Kultura i obitelj. Zavičajna baština - komparativna prednost i temeljnica održivog razvoja Zabiokovlja, Split: Književni krug.

\title{
STUDENTS' ATTITUDES ABOUT THE MUSEUM AS A LEARNING ENVIRONMENT
}

\author{
Dubravka Kuščević, Marija Brajčić, Zvonimira Talijan
}

In the modern world, museums as cultural institutions are constantly striving to attract the attention of educational institutions with their pedagogical activities. The theoretical part of the paper emphasizes the educational role of museums, describing the key elements and the main characteristics of learning in the museum. In the empirical part of the paper, we present the results of the research that show the attitudes of students from both social and natural sciences towards visiting museums, on the teaching of Art science in the museum, and on the use of museums as an area for informal learning.

The study was conducted among students of the Teacher Education and PreSchool Education at the Faculty of Humanities and Social Sciences, University of Split, students at the Faculty of Economics, Faculty of Natural Sciences and Mathematics and students of the Faculty of Medicine, University of Split. A total of 158 students were included: 52 students of natural sciences and 106 from the field of social sciences. Of the total number of students, 147 were women, and 11 were men. The results showed that students of social and natural sciences have the same attitudes, i.e., both groups mostly agree with the claims which express positive attitudes about the importance of museum as good learning environment.

Key words: culture, museum as an environment, learning, students, attitudes 


\section{Prilog 1. Anketni upitnik}

\section{Zaokružite!}

\begin{tabular}{|c|c|c|}
\hline Studij & & \\
\hline Spol & a) muški & b) ženski \\
\hline Studijska godina & a) $1 . \quad$ b) 2 & $\begin{array}{lll}\text { c) } 3 . & \text { d) } 4 . & \text { d.) } 5\end{array}$ \\
\hline Mjesto pohađanja osnovne škole & a) selo & b) grad \\
\hline
\end{tabular}

\section{Pažljivo pročitajte svaku tvrdnju i opredijelite se za jedan od mogućih odgovora predstavljenih brojevima.}

Brojevi imaju sljedeće značenje: 1 - uopće se ne slažem, 2 - uglavnom se ne slažem, 3 - ne znam, 4 - uglavnom se slažem, 5 - u potpunosti se slažem.

Molimo da odaberete samo jedan odgovor koji se odnosi na Vaše mišljenje.

\begin{tabular}{|c|c|c|c|c|c|c|}
\hline & Tvrdnje & 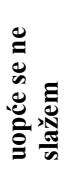 & 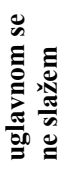 & 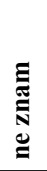 & 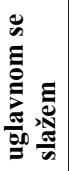 & 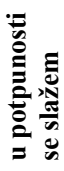 \\
\hline 1. & $\begin{array}{l}\text { Učenje je intenzivnije pomoću vizualnog } \\
\text { doživljaja. }\end{array}$ & 1 & 2 & 3 & 4 & 5 \\
\hline 2. & Doživljaj često nadilazi riječi. & 1 & 2 & 3 & 4 & 5 \\
\hline 3. & $\begin{array}{l}\text { Učenje u muzeju povezuje kognitivno i } \\
\text { afektivno učenje. }\end{array}$ & 1 & 2 & 3 & 4 & 5 \\
\hline 4. & $\begin{array}{l}\text { Učenje u muzeju različito je od učenja u } \\
\text { učionici. }\end{array}$ & 1 & 2 & 3 & 4 & 5 \\
\hline 5. & Učenje u muzeju učinkovito je za djecu. & 1 & 2 & 3 & 4 & 5 \\
\hline 6. & Prakticiram samostalni odlazak u muzej. & 1 & 2 & 3 & 4 & 5 \\
\hline 7. & $\begin{array}{l}\text { Muzejske radionice potaknut će dječju } \\
\text { naklonost prema Likovnoj kulturi. }\end{array}$ & 1 & 2 & 3 & 4 & 5 \\
\hline 8. & $\begin{array}{l}\text { Muzejske radionice potiču dječju kreativnost } \\
\text { i inovativnost. }\end{array}$ & 1 & 2 & 3 & 4 & 5 \\
\hline 9. & $\begin{array}{l}\text { Muzejske aktivnosti pogodne su samo za } \\
\text { nastavu Likovne kulture. }\end{array}$ & 1 & 2 & 3 & 4 & 5 \\
\hline
\end{tabular}

